\title{
ISSR Primerleri ile Kültürü Yapılan Bazı Yonca (Medicago sativa L.) Ekotiplerinde Moleküler Farklılıkların Belirlenmesi
}

\author{
${ }^{*}$ Mehmet Macit ERTUŞ ${ }^{1} \quad$ Cafer Olcayto SABANCl ${ }^{2} \quad$ Suat ŞENSOY ${ }^{3}$
}

${ }^{1}$ Hakkari Üniversitesi, Çölemerik MYO, Bitkisel ve Hayvansal Üretim Bölümü, Hakkari

${ }^{2}$ Ahi Ervan Üniversitesi, Ziraat Fakültesi Tarla Bitkileri Bölümü, Kırşehir

${ }^{3}$ Yüzüncü Yıl Üniversitesi, Ziraat Fakültesi, Bahçe Bitkileri Bölümü, Van

*Sorumlu yazar e-posta (Corresponding author e-mail): mehmetmacitertus@hakkari.edu.tr

Öz

Bu çalışma, Van ili ve çevre illerden toplanan 70 adet yonca (Medicago sativa L.) ekotipi ile 6 tescilli çeşit olmak üzere toplam 76 genotip arasındaki akrabalık ilişkilerinin belirlenmesi amacıyla yürütülmüştür. 12 adet ISSR primeri kullanılmış ve 85 polimorfik bant elde edilmiştir. Ekotipler arasındaki genetik uzaklıklar Öklid katsayısı yardımıyla belirlenmiştir. Yonca ekotiplerinin toplandığı bölgelere göre, ayrıca yerel çeşit olarak ve tescilli çeşitler olmak üzere toplam 16 grup altında genetik varyasyonu incelenmiştir. En yüksek genetik çeşitlilik $(H=0.245$ ve I = 0.366) ve polimorfizm (\%70.59) olarak Gürpınar ekotiplerinde içerisinde gözlenmiştir. Yabancı döllenen Medicago sativa'nın ekotip ve çeşitler arasında yüksek genetik çeşitliliğe sahip olduğu belirlenmiştir.

Anahtar Kelimeler: Yonca, Medicago sativa, ISSR, genetik çeşitlilik

\section{Determination of Molecular Diversity with ISSR Markers in Some Cultivated Alfalfa (Medicago sativa L.) Ecotypes}

\begin{abstract}
The relationships among total 76 ecotypes of alfalfa (Medicago sativa L.), 70 landraces and 6 cultivars, collected in Van and neighboring provinces were investigated in the present study. In the molecular method, Twelve ISSR primers were used and 85 polymorphic bands were obtained. The genetic distances between the ecotypes were expressed by Euclidean coefficients. The genetic variation among alfalfa ecotypes was examined in 16 groups based on the localities, landraces and check cultivars. The highest genetic variations and polymorphisms $(\mathrm{H}=0.245, \mathrm{I}=0.366$, and $70.59 \%)$ were found in Gurpinar localities. As a result, a high genetic diversity was found out among the ecotypes and cultivars of allogamous Medicago sativa L.
\end{abstract}

Keywords: Alfalfa, Medicago sativa, ISSR, genetic diversity

\section{Giriş}

ü kemizde toplam ekilen 16.581 .603 ha alan içerisinde 1.585.681 ha yem bitkileri ekimi gerçekleşmektedir. Yem bitkileri içerisinde 555.722 ha yonca ekim alanı ile fiğden sonra gelmektedir. Doğu Anadolu Bölgesi 585.433 ha yem bitkileri ekim alanıyla ilk sırada yer alırken bu alanın yaklaşık \%60'ında (348.407 ha) yonca tarımı yapılmaktadır (Sabancı ve ark. 2010). Çok yıllık olması, yıl içerisinde birden fazla biçim vermesi, besleyici olması özellikleri ile yonca (Medicago sativa L.) hayvan beslenmesinde vazgeçilmez bir yem bitkisidir. Dünya üzerinde 32 milyon hektar ekilen yonca'nın orijini Kafkasya, Kuzeydoğu Türkiye, Kuzeybatı İran ve Türkmenistan'dır (Michaud et al. 1988). Bölgede yüzyıllardır tarımı yapılan yoncayı iyi tanıyan çiftçi elindeki tohumu sürekli muhafaza ettiği gibi çevre illerden de tohum temin yoluna gitmiştir. Doğu Anadolu Bölgesi'nin yoncanın gen merkezi olması yanında Van ili ve ilçelerinde çiftçinin elinde bulundurduğu tohumluğun çeşit geliştirmek ve gen kaynağı olarak kullanılması göz önüne alınmalıdır. Çeşitlerin karakterizasyonunda morfolojik ve biyokimyasal belirteçlerin yerine, son yıllarda DNA belirteçleri kullanılmaktadır. Ünverdi (2007)'nin bildirdiğine göre Tanksley et al. (1989), bitkilerde genetik ilişkileri ortaya çıkarmak için kullanılan ilk DNA işaretleyicisi RFLP'dir (Restricted Fragment Length 
Polymorphism: Kesilmiş Parça Uzunlukları Polimorfizmi). RFLP yönteminin maliyetinin çok yüksek ve yavaş olması, PCR temelli moleküler işaretleyicilerin gelişmesine sebep olmuştur. Bu yöntemlerden bazıları, RAPD (Random Amplified PolimorphicDNAs), AFLP (Amplified Fragment Length Polimorphisms), SSR (Simple Sequense Repeats) ve ISSR'dir (Intersimple Sequence Repeats). Bu tekniklerden RAPD, AFLP, SSR ve ISSR DNA işaretleyicileri, kültür bitkilerinde genetik çeşitliliğin saptanmasında yoğun olarak kullanılmaktadır (Özcan ve ark. 2004). Bazı araştırmacılar ISSR yönteminin de yonca da akrabalık derecelerinin belirlenmesinde kullanılacağını bildirmişlerdir (Touil et al. 2008; Petolescu and Nedelea, 2009). Bu araştırma ile yoncanın gen merkezi içinde olan Van ilinde ekimi yapılan ekotipler ve bazı tescilli çeşitler arasında akrabalık derecelerinin belirlenmesi amaçlanmıştır.

\section{Materyal ve Yöntem}

Çalışma materyali olarak Van ilinin değiş̧ik yörelerinde kültürü yapılan yerel yonca (Medicago sativa L.) çeşitleri kullanıımış, ayrıca ülkemizde ekimi yapılan altı çeşit (Planet, MA324, Kalender, Alsancak, Elçi ve Bilensoy80) denemede yer almıştır. Van ilinin Merkez, Çaldıran, Saray, Özalp, Muradiye, Erciş, Çatak, Başkale, Gürpınar, Gevaş ilçelerinde denizden yüksekliği 1680-2353 m yükseltiler arasında olan köylerden 62 yonca ekotipi (yerel çeşit) toplanmıştır. Ayrıca Bitlis ilinin Ahlat ve Hizan ilçelerinden sağlanan 4 ekotip, Siirt ilinden temin

Çizelge 1. Çalışmada Kullanılan Yonca Ekotiplerine Ait Bilgiler Table 1. Information about Alfalfa ecotypes used in this study

\begin{tabular}{|c|c|c|c|c|c|c|c|}
\hline No & İI & İlçe & Köy & No & İI & İlçe & Köy \\
\hline 1 & Van & Özalp & Aksurguç & 36 & Van & Çatak & Kayaboğazı \\
\hline 2 & Van & Özalp & Merkez & 37 & Van & Çatak & Uzuntekne \\
\hline 3 & Van & Merkez & Kıratlı & 38 & Van & Çatak & Alacayar \\
\hline 4 & Van & Merkez & Erçek & 39 & Van & Çatak & Alacayar \\
\hline 5 & Van & Merkez & Değirmenarkı & 40 & Van & Çatak & Alacayar \\
\hline 6 & Van & Merkez & Tohumcu* & 41 & Van & Çatak & Teknecik \\
\hline 7 & Van & Merkez & Tohumcu* & 42 & Van & Çatak & Ağaçlık \\
\hline 8 & Van & Çaldıran & Yukarıyanıktaş & 43 & Van & Gevaş & Yuva \\
\hline 9 & Van & Çaldıran & Doyumalan & 44 & Van & Gevaş & Merkez \\
\hline 10 & Van & Çaldıran & Kurtoğlan & 45 & Van & Gevaş & Koçak \\
\hline 11 & Van & Çaldıran & Boğulukaynak & 46 & Van & Gevaş & Göründü \\
\hline 12 & Van & Çaldıran & Salhane & 47 & Van & Gevaş & Yemişlik \\
\hline 13 & Van & Çaldıran & Kılavuz & 48 & Van & Gevaş & Abalı \\
\hline 14 & Van & Çaldıran & İncealan & 49 & Van & Gevaş & Balaban \\
\hline 15 & Van & Başkale & Albayrak & 50 & Van & Saray & Çaybağı \\
\hline 16 & Van & Başkale & Barış & 51 & Van & Saray & Değirmigöl \\
\hline 17 & Van & Başkale & Merkez & 52 & Van & Saray & Sırımlı \\
\hline 18 & Van & Başkale & Yolmaçayır & 53 & Van & Saray & Değirmigöl \\
\hline 19 & Van & Muradiye & Merkez & 54 & Van & Gürpınar & Merkez \\
\hline 20 & Van & Muradiye & Yenişehir mah. & 55 & Van & Gürpınar & Yukarıkaymaz \\
\hline 21 & Van & Muradiye & Yumaklı & 56 & Van & Gürpınar & Koyunyatağı \\
\hline 22 & Van & Muradiye & Yumaklı & 57 & Van & Gürpınar & Değirmendüzü \\
\hline 23 & Van & Erciş & Taşlıçay & 58 & Van & Gürpınar & Bozyiğit \\
\hline 24 & Van & Erciş & Merkez & 59 & Van & Gürpınar & Değirmendüzü \\
\hline 25 & Van & Erciş & Merkez & 60 & Van & Gürpınar & Sakalar \\
\hline 26 & Van & Erciş & Pay & 61 & Van & Gürpınar & Merkez \\
\hline 27 & Van & Erciş & Keklikova & 62 & Van & Gürpınar & Bozyiğit \\
\hline 28 & Van & Erciş & Kozluca & 63 & Bitlis & Ahlat & Güzelsu \\
\hline 29 & Van & Erciş & Karlıyayla & 64 & Bitlis & Ahlat & Güzelsu \\
\hline 30 & Van & Erciş & Merkez & 65 & Siirt & Merkez & Tarım İl Md. \\
\hline 31 & Van & Erciş & Karlıyayla & 66 & Siirt & Merkez & Tarım İl Md. \\
\hline 32 & Van & Erciş & Taşevler & 67 & Van & Merkez & Kampüs \\
\hline 33 & Van & Erciş & Kocapınar & 68 & Van & Merkez & Kampüs \\
\hline 34 & Van & Erciş & Merkez & 69 & Bitlis & Hizan & Hizan \\
\hline 35 & Van & Erciş & Kocapınar & 70 & Bitlis & Hizan & Hizan \\
\hline
\end{tabular}

* İlçe merkezlerinde bulunan ve değişik köylerden gelen tohumları piyasaya süren ticarethaneler

* The firms sell seeds come from different villages to the pazar and these firms are located in central of districts 
Çizelge 2. Çalışmada kullanılan Yonca Çeşitleri

Table 2. Alfalfa genotypes used in this study

\begin{tabular}{llllll}
\hline No & Adı & No & Adı & No & MA-324 \\
\hline 71 & Elçi & 73 & Kalender & 75 & Planet \\
72 & Alsancak & 74 & Bilensoy-80 & 76 & . \\
\hline
\end{tabular}

edilen 2 ekotip ve Yüzüncü Yıl Universitesi Kampüs alanında kendiliğinden yetişen 2 ekotip denemeye alınmıştır. Tescilli çeşitlerle birlikte toplam 76 adet genotip incelenmiştir. Denemede kullanılan ekotiplere ilişkin bilgiler Çizelge 1'de verilmiştir.

Populasyonu temsil edecek şekilde (her popülasyondan 15 bitki), DoyleandDoyle (1987)'un bildirmiş olduğu metottaki küçük bir değişiklik ile CTAB (hexadecyltrimethylammoniumbromide) izolasyon yöntemine göre gerçekleştirilmiştir. Spektrofotometre ile DNA örnekleri, $1 \mu$ INA + $100 \mu \mathrm{l}$ su şeklinde 100 kat sulandırılmış ve UV spektrofotometre cihazında $260 \mathrm{~nm}$ ve $280 \mathrm{~nm}$ dalga boylarında sırasıyla DNA için ve protein için absorbans değerleri ölçülmüştür. DNA ölçümleri sonucunda örnek konsantrasyonlarına ddH2O ilave edilerek 50 ng olarak seyreltilmiştir (Anonim, 2010).

PCR reaksiyonu için herbir PCR tüpüne toplam $20 \mu \mathrm{l}$ olarak ayarlanacak şekilde, 10Xbuffer $(2.5 \mu \mathrm{l}), 200 \mathrm{mMdNTP}(2.0 \mu \mathrm{l}), 50$ $\mathrm{mM} \mathrm{MgCl}{ }^{2}(0.75 \mu \mathrm{l}), 5 \mathrm{mM}$ of primer $(1.0 \mu \mathrm{l}), 1$ $\mathrm{U}$ Taqpolimeraz $(0.2 \mu \mathrm{l}), 12.50 \mu \mathrm{lsaf}$ su ve $1 \mu \mathrm{l}$ (50 ng) DNA ilave edilmiştir(Paredes et. al., 2002). DNA ayrılma için $92^{\circ} \mathrm{C}$ 'de 4 dakika, 35 döngü olmak üzere $92^{\circ} \mathrm{C}$ de 1 dakika, primer bağlanması için sıcaklıklar Çizelge 3'de, uzama için $72^{\circ} \mathrm{C}$ 'de 2 dakika ve 35 döngüden sonra son uzama için $72^{\circ} \mathrm{C}$ 'de 6 dakika PCR reaksiyonu tamamlanmıştır (Paredes et al. 2002; Reddy et al. 2002; Belaid et al. 2006; Ünverdi 2007; Petolescu and Nedelea 2009).

PCR ürünleri, agoroz jel elektroforezinde (\%1.5 agoroz jelde 90 V'da 1x TAE tamponu içerisinde 3 saat koşturularak) moleküler ağırıklarına göre ayrımlanmış; ethidiumbromid ile boyandıktan sonra bantlar, UV altında görünür hale getirilip, genotiplerin oluşturduğu değişik bantlar, bant varlığı (1) veya yokluğu (0) şeklinde belirlenmiştir. Monomorfik bantlar analiz dışı bırakıımıştır (Şensoy 2005; Ünverdi 2007; Alınca 2008). Genotipler arasındaki genetik uzaklıklar ise değişik benzerlik indeksi katsayıları (Öklid katsayısı) yardımıyla belirlenmiş ve dendrogramlar, ağırlıklı olmayan aritmetik ortalama eş grup metoduna (UPGMA:
Unweighted Pair Group Method with Arithmatic Mean) göre hazır paket programı NTSYSpc2.02k ile oluşturulmuştur(Rohlf, 1997).Yonca ekotip ve çeşitleri arasındaki genetik varyasyon, ekotipleri bölge ve çeşit tiplerine göre populasyonlara ayırarak ve POPGENE hazır paket programı kullanılarak belirlenmiştir (Yeh et al. 1997; Labate 2000). POPGENE programıyla Nei ve Shannon genetik çeşitlilik indeksleri ve polimorfizm oranları belirlenmiştir (Yeh et. al., 1997).

\section{Bulgular ve Tartışma}

ISSR primerleri sonucu \%28.57 ile \%78.57 arasında polimorfizm elde edilmiştir. Toplam 126 adet olan bantların 85'i polimorfik olarak elde edilmiştir. Petolescu and Nedelea (2009) Medicago sativa'nın bazı hat ve çeşitlerinde genetik çeşitliliği belirlemek için ISSR primerlerini (A12, A13, A17, A21 ve UBC818) polimorfizm oranını \%5.57 ile \%66.79 arasında değiştiğini bildirmişlerdir.

ISSR primerleri kullanılarak akrabalık derecesinin belirlenmesinde Öklid katsayısı kullanılarak elde edilmiş matris sonucu genotipler arasındaki en yakın benzerlik (2.24E+00 öklid katsayısı) 20 ile 21 numaralı Muradiye ekotipleri arasında belirlenmiştir. Genotipler arasındaki en uzak benzerlik $6.00 \mathrm{E}+00$ öklid katsayısı ile 50 numaralı Saray ekotipi ile 56 numaralı Gürpınar ve 70 numaralı Hizan ekotipleri arasında belirlenmiştir.

Genotipler arasında diğer genotiplere benzerliği ortalama olarak en yüksek olan genotip 4.21E+00 öklid katsayısı değeriyle 16 numaralı Başkale ekotipi iken en düşük olan genotip 5.14E+00 öklid katsayısı değeriyle 75 numaralı MA-324 çeşidi olarak belirlenmiştir.

ISSR verileri sonucu Öklid matrisi katsayısı ile elde edilen dendrogramın incelenmesiyle 8 ana ve 4 alt grup altında incelemek mümkün olmuştur. 2 ve 7 numaralı Van ekotipleri ile 73 numaralı Kalender ve 75 numaralı MA-324 çeşitleri diğerlerinden çok farklı bir dallanma göstermiştir. Siirt ve Hizan ekotiplerinin tümü ve 5 farklı ekotip A1 alt grubunda yer almıştır. Elçi (71), Alsancak (72) ve Planet (76) çeşitleri ile 6 ekotip A2 grubunda görülmektedir. Toplam 7 
Çizelge 3. ISSR primerleri ve elde edilen bazı değerler Table 3. ISSR primers and results

\begin{tabular}{llcccc}
\hline Kod & Dizilişi & $\begin{array}{c}\text { Bağlanma } \\
\text { Sıcaklığı }\left({ }^{\circ} \mathrm{C}\right)\end{array}$ & $\begin{array}{c}\text { Polimorfik } \\
\text { bant sayısı }\end{array}$ & $\begin{array}{c}\text { Toplam } \\
\text { bant sayısı }\end{array}$ & $\begin{array}{c}\text { Polimorfik } \\
\text { oranı }(\%)\end{array}$ \\
\hline A12 & $(\mathrm{GA})_{6} \mathrm{CC}$ & 44 & 2 & 7 & 28.57 \\
UBC-818 & $(\mathrm{CA})_{7} \mathrm{G}$ & 45 & 7 & 12 & 58.33 \\
$3 \mathrm{X}$ & $(\mathrm{AG})_{10} \mathrm{C}$ & 61 & 9 & 11 & 81.82 \\
$4 \mathrm{X}$ & $(\mathrm{TC})_{10} \mathrm{~A}$ & 57 & 12 & 13 & 92.30 \\
$5 \mathrm{X}$ & $(\mathrm{AG})_{10}$ & 54 & 2 & 6 & 33.33 \\
A2 & $(\mathrm{ACTG})_{5}$ & 56 & 16 & 16 & 100 \\
A3 & $(\mathrm{GACA})_{5}$ & 55 & 9 & 12 & 75.00 \\
A7 & $(\mathrm{AG})_{10} \mathrm{~T}$ & 55 & 2 & 5 & 40.00 \\
A10 & $(\mathrm{CT})_{10} \mathrm{~T}$ & 55 & 5 & 9 & 55.56 \\
A13 & $(\mathrm{GT})_{6} \mathrm{CC}$ & 44 & 11 & 14 & 78.57 \\
A17 & $(\mathrm{GTG})_{3} \mathrm{GC}$ & 38 & 5 & 10 & 50.00 \\
A21 & $(\mathrm{CA})_{6}$ AC & 41 & 5 & 11 & 45.45 \\
\hline Toplam & & & 85 & 126 & \\
\hline
\end{tabular}

Çizelge 4. Yonca ekotipleri arasında gruplar bazında ölçülen bazı genetik varyasyon ölçütleri Table 4. Genetic diversity parameters of alfalfa ecotype groups

\begin{tabular}{llllc}
\hline Ekotipler/Çeşitler & $\mathrm{N}^{*}$ & $\mathrm{H}$ & $\mathrm{I}$ & \% Polimorfizm \\
\hline Van/Özalp & 2 & 0.117 & 0.170 & 28.24 \\
Van/Merkez & 5 & 0.171 & 0.255 & 47.06 \\
Van/Çaldıran & 7 & 0.194 & 0.290 & 55.29 \\
Van/Başkale & 4 & 0.109 & 0.162 & 29.41 \\
Van/Muradiye & 4 & 0.082 & 0.122 & 22.35 \\
Van/Erciş & 13 & 0.237 & 0.352 & 65.88 \\
Van/Çatak & 7 & 0.193 & 0.288 & 55.29 \\
Van/Gevaş & 7 & 0.215 & 0.317 & 57.65 \\
Van/Saray & 4 & 0.197 & 0.284 & 47.06 \\
Van/Gürpınar & 9 & 0.245 & 0.366 & 70.59 \\
Bitlis/Ahlat & 2 & 0.107 & 0.156 & 25.88 \\
Siirt & 2 & 0.058 & 0.085 & 14.12 \\
Van/Kampüs & 2 & 0.083 & 0.121 & 20.00 \\
Bitlis/Hizan & 2 & 0.073 & 0.107 & 17.65 \\
Tescilli çeşit & 6 & 0.237 & 0.348 & 61.18 \\
Yerel çeşitler & 70 & 0.305 & 0.463 & 95.92 \\
Bütün Ekotipler & 76 & 0.274 & 0.428 & 100 \\
\hline
\end{tabular}

${ }^{*} \mathrm{~N}=$ Populasyondaki genotip sayısı; $\mathrm{H}=$ Nei'nin genetik çeşitlilik indeksi; $\mathrm{I}=$ Shannon'un genetik çeşitlilik indeksi ${ }^{*} N=$ Number of genotypes in population; $H=N e i$ 's genetic diversity index; $I=$ Shannon's genetic diversity index

adet olan Çaldıran ekotiplerinin 6'sı ve 5 adet olan Başkale ekotiplerinin 4'ü B1 alt grubunda konumlanmışlardır. Erciş ekotiplerinin 9 adedi, Muradiye ekotiplerinin 4 adedi ve Çatak ekotiplerinin 3 adedi B2 alt grubunda yer almıştır. Birbirine en yakın özellik gösteren 20 ve 21 numaralı Muradiye ekotiplerinin de B2 alt grubunda olduğu görülmektedir. Küçük gruplar oluşturan C'de 3, D'de 2 ve E'de 2 ekotip bulunmaktadır.

Gürpınar ekotiplerinden 3 ve bir adet Ahlat ekotipini içine alan $\mathrm{F}$ grubunda Bilensoy-80 çeşidinin de yer aldığı görülmektedir. Van ve Gürpınara ait 2 ekotipi $\mathrm{G}$ grubu oluşturmuş, $\mathrm{H}$ grubunun Erciş'in 2, Gürpınar'ın 2 ve bir Ahlat ekotipini içine aldığı görülmüştür (Şekil 1).
ISSR verilerine göre elde edilen istatistiksel varyasyon ölçütleri, değerlendirilen ekotiplerdeki populasyon yapısının bölgelere bağlı olarak farklılık içerdiklerini göstermiştir. En yüksek genetik çeşitlilik $(\mathrm{H}=0.245$ ve I $=0.366)$ ve polimorfizm (\%70.59) olarak Gürpınar ekotiplerinde içerisinde gözlenmiştir. Erciş ekotipleri arasındaki genetik varyasyon değerleri $(\mathrm{H}=0.237, \mathrm{I}=0.352$, polimorfizm \%65.88) de oldukça yüksek bulunmuştur. Yerel çeşitler arasında $\mathrm{H}=0.305, \mathrm{I}=0.463$ ve $\% 95.92$ polimorfizm oranı ile $\mathrm{H}=0.327, \mathrm{I}=$ 0.348 ve $\% 61.18$ polimorfizm oranına sahip tescilli çeşitlerden genetik farklılıkların oldukça yüksek olduğu, tüm ekotip ve tescilli çeşitler arasında $\mathrm{H}=0.274, \mathrm{I}=0.428$ ve $\% 100$ 


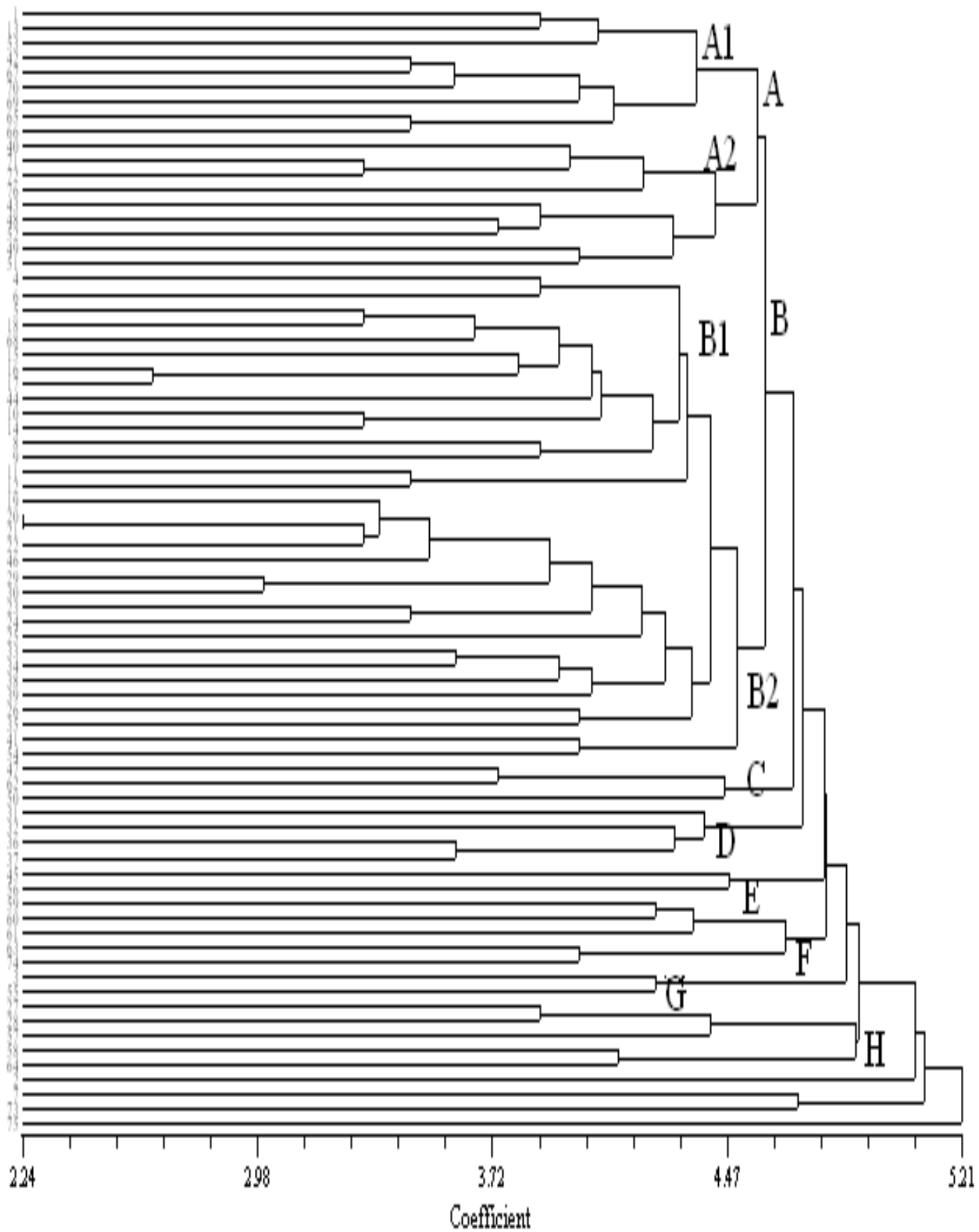

Şekil 1. ISSR belirteçleri ile akrabalık derecesinin belirlenmesinde öklid matrisi kullanılarak UPGMA ile elde edilmiş dendrogram.

Figure 1. Dendogram of genetic distances with ISSR markers between ecotypes by euclidean coefficients, group average unweighted (UPGMA)

polimorfizm oranıyla genetik çeşitliliğin yüksek olduğu görülmüştür (Çizelge 4).

\section{Sonuç}

Çalışma sonucunda birbirine çok yakın ekotip veya çeşit tespit edilememiştir. Yonca'nın (Medicao sativa L.) yabancı döllenmesi ve tetraploid kromozom setine sahip olması genetik varyasyonun yüksek olmasına neden olmaktadır.

\section{Teşekkür}

Bu yayın doktora tezinden alınmış ve Yüzüncü Yıl Üniversitesi BAPB tarafından,2010-FBE-D037 numaralı proje olarak desteklenmiştir. 


\section{Kaynaklar}

Anonim, 2010.Tür ve Irkların DNA İşaretleri ile Moleküler Tanımlanması Çalışma Paketi. TÜBITAK TÜRKHAYGEN-1 Projesi. I. Çalıştay, 2-3 Nisan 2007, ODTÜ http://www.turkhaygen.gov.tr/doc/egitim_ODT U.pdf..(Erişim tarihi: 06.03.2010)

Alınca S., 2008. Güneydoğu Anadolu Bölgesinden toplanan buton yoncasının (Medicago orbicularis) morfolojik özellikleri ve moleküler karakterizasyonu. Yüksek Lisans tezi. Dicle Üniversitesi Fen Bilimleri Enstitüsü (Basılmamış). Diyarbakır.

Belaid Y., Chtourou-Ghorbel N., Marrakchi M. and TrifiFarah N., 2006. Genetic diversity with in and between populations of Lathyrus genus (Fabaceae) revealedby ISSR markers. Genetic Resources and Crop Evolution. 53: 1413-1418.

Doyle J.J. and Doyle J.L. 1987. A rapid DNA isolation procedure from small quantities of fresh leaf tissues. Phytochem. Bull. 19: 11-15.

Labate J.A., 2000. Software for population genetic analyses of molecular marker data. Crop. Sci., 40:1521-1528.

Michaud R., Lehman W.F. and Runbaugh M.D., 1988. World distribution and historical development. InHanson AA, Barnes DK, Hill RR (eds) ASA, CSSA, SSSA, Madison, WI, Agronomy, Series of Monographs 29:25-91.

Özcan S., Gürel E. ve Babaoğlu M., 2004. Bitki Biyoteknolojisi. S.Ü. Vakfı Yayınları. Konya. 456.

Paredes M., Becerra V., Rojo C., Del Pozo A., Ovalle C. and Aronson J., 2002. Ecotypic differentiation in Medicago polymorpha L. along an environmental gradient in central Chile. RAPDs studies show little genetic divergence. Euphtica, 123:431-439.

Petolescu C. and Nedelea G., 2009. Genetic diversity analysis of the invitro regenerated alfalfa plants using Inter Simple Sequence Repeat (ISSR) markers. Romanian Biotechnological Leters, 14(6): 4882-4886.
Reddy M.P., Sarla N. and Siddiq E.A., 2002. Inter Simple SequenceRepeat (ISSR) poly morphism and its application in plantbreeding. Euphytica, 128:9-17.

Rohlf F.J., 1997. NTSYS-pc: Numerical Taxonomy and Multivariate Analysis System. Exeter Software, New York.

Sabancı C.O., Baytekin H., Balabanlı C. ve Acar Z., 2010. Yem bitkileri üretiminin arttırılması olanakları. Türkiye Ziraat Mühendisliği VII. Teknik Kongresi. 11-15 Ocak 2010. Ankara Cilt I. 343-360

Şensoy S., 2005. Türkiye Kavunlarındaki Genetik Varyasyonun ve Fusarium Solgunluğuna Dayanıklılığın Fenotipik ve Moleküler Yöntemlerle Araştırılması. Doktora tezi. YYÜ Fen Bilimleri Enstitüsü (Basılmamış). Van.

Tanksley S.D., Young N.D., Paterson A.H. and Bonierbale M.W., 1989. RFLP mapping in plant breeding: new tools for old sciences. Biotechnology, 7:257-264.

Touil L., Guesmi F., Fares K. and Ferchichi A., 2008. Genetic diversity of some Mediterranean populations of the cultivated alfalfa (Medicago sativa L.) using ISSR markers. Biotechnology, 7 (4): 808-812.

Ünverdi M.A., 2007. Türkiye'de Tescil Ettirilmiş Bazı Fiğ (Vicia sativa L.) Çeşitleri Arasındaki Morfolojik Ve Moleküler Farklılıkların Saptanması Üzerine Bir Araştırma. Yüksek Lisans tezi. Çukurova Üniversitesi. Fen Bilimleri Enstitüsü (Basılmamış). Adana.

Yeh F.C., Yang R.C., Boyle T.B.J., Ye Z.H. and Mao, J.K., 1997. POPGENE, the User Friendly Sharewarefor PopulationGenetic Analysis. University of Alberta, Canada. Molecular Biology and Biotechnology Centre. 